\title{
PEMODELAN INDEKS HARGA KONSUMEN DI JAWA TENGAH DENGAN METODE GENERALIZED SPACE TIME AUTOREGRESSIVE SEEMINGLY UNRELATED REGRESSION (GSTAR-SUR)
}

\author{
Mega Fitria Andriyani ${ }^{1}$, Abdul Hoyyi ${ }^{2}$, Hasbi Yasin ${ }^{3}$ \\ 1,2,3 Departemen Statistika, Fakultas Sains dan Matematika, Universitas Diponegoro \\ e-mail : hoyyistat@gmail.com
}

\begin{abstract}
The Generalized Space Time Autoregressive (GSTAR) model with Seemingly Unrelated Regression (SUR) estimation method or often called GSTAR-SUR is more efficient to be used for residual correlation than Ordinary Least Square (OLS) estimation method. The SUR estimation method utilizes residual correlation information to improve the estimated efficiency resulting in a smaller standard error. The purpose of this research is to get the GSTAR-SUR model according to Consumer Price Index (CPI) data in four regencies or cities in Central Java namely Purwokerto, Surakarta, Semarang, and Tegal. Based on the assumed white noise as sumption, the smallest MAPE and RMSE averages, the best model chosen in this research is the GSTARSUR $\left(1_{1}\right) I(1)$ model with the heavy of normalized cross-correlation with the average MAPEvalue of $0.4455 \%$ and RMSE value of 0.80582. The best model obtained explains that the CPI data in Purwokerto, Semarang, and Tegal not only influenced by the previous time but also influenced by the locations. Meanwhile, the CPI data in Surakarta is only influenced by the previous time, but it is not affected by other locations.
\end{abstract}

Keywords: SUR, OLS, Consumer Price Index

\section{PENDAHULUAN}

Inflasi merupakan perubahan dari Indeks Harga Konsumen (IHK). Perubahan IHK merupakan salah satu indikator ekonomi makro yang cukup penting untuk memberikan gambaran tentang laju inflasi suatu daerah/wilayah dan pola konsumsi masyarakat. Penentuan jumlah, jenis, dan kualitas dalam paket komoditi barang dan jasa serta bobot timbangannya dalam IHK didasarkan pada Survei Biaya Hidup (SBH). Di Jawa Tengah ada empat kota yang dicakup dalam pelaksanaan SBH yaitu Purwokerto, Surakarta, Semarang, dan Tegal (BPS, 2014). IHK di empat kota tersebut memungkinkan dipengaruhi oleh waktu sebelumnya dan memiliki keterkaitan dengan lokasi lain disebut dengan hubungan spasial.

Model space-time pertama kali diperkenalkan oleh Pfeifer dan Deutsch (1980). Model Space-Time Autoregressive (STAR) mengasumsikan bahwa lokasi yang diteliti memiliki karakteristik homogen, Sedangkan model Generalized Space-Time Autoregressive (GSTAR) mengasumsikan bahwa lokasi yang diteliti memiliki karakteristik heterogen. Kajian estimasi parameter penelitian tentang GSTAR yang sudah ada, masih terbatas pada estimasi dengan metode Ordinary Least Square (OLS) (Borovkova et al., 2008). Estimasi parameter OLS pada model GSTAR dengan residual saling berkorelasi akan menghasilkan estimator yang tidak efisien. Salah satu metode yang sesuai untuk mengestimasi parameter dengan residual yang saling berkorelasi adalah Generalized Least Square (GLS), biasanya digunakan dalam model Seemingly Unrelated Regression (SUR) (Srivastava dan Dwivedi, 1979). Oleh karena itu, dalam penelitian ini akan diterapkan metode GSTAR dengan estimasi parameter menggunakan metode Seemingly Unrelated Regression (SUR) untuk pemodelan data IHK Jawa Tengah di Purwokerto, Surakarta, Semarang, dan Tegal.

\section{TINJAUAN PUSTAKA}

\subsection{Multivariate Time Series}

Multivariate time series adalah serangkaian data yang terdiri atas beberapa variabel yang diambil dari waktu ke waktu dan dicatat secara berurutan menurut waktu kejadiannya 
dengan interval waktu yang tetap. Stasioneritas dari multivariate time series dapat dilihat dari plot Matrix Autocorrelation Function (MACF) dan Matrix Partial Autocorrelation Function (MPACF) (Wei, 2006).

\subsubsection{Matrix Autocorrelation Function (MACF)}

Diberikan sebuah vektor time series dengan observasi sebanyak $\mathrm{T}$, yaitu $Z_{1}, Z_{2}, \ldots, Z_{T}$, maka persamaan matriks korelasi sampelnya adalah sebagai berikut (Wei, 2006):

$\widehat{\boldsymbol{\rho}}(k)=\left[\hat{\rho}_{i j}(k)\right]$

dengan $\hat{\rho}_{i j}(k)$ merupakan korelasi silang sampel untuk komponen lokasi ke-i dan ke-j yang dinyatakan dalam persamaan berikut:

$\hat{\rho}_{i j}(k)=\frac{\sum_{t=1}^{T-k}\left(Z_{i, t}-\bar{Z}_{i}\right)\left(z_{j, t+k}-\bar{Z}_{j}\right)}{\left[\sum_{t=1}^{T}\left(Z_{i, t}-Z_{i}\right)^{2} \Sigma_{t=1}^{T}\left(z_{j, t}-Z_{j}\right)^{2}\right]^{\frac{1}{2}}}$

dimana $\bar{Z}_{i}$ dan $\bar{Z}_{j}$ adalah rata-rata sampel dari komponen lokasi yang bersesuaian.

Tiao dan Box (1981) dalam Wei (2006) memperkenalkan sebuah metode yang sesuai untuk meringkas penjelasan korelasi sampel. Simbol $(+)$ diartikan sebagai $\hat{\rho}_{i j}(k)$ lebih dari 2 kali standard errors dan menunjukkan adanya korelasi positif, (-) diartikan sebagai $\hat{\rho}_{i j}(k)$ kurang dari -2 kali standard errors dan menunjukkan adanya korelasi negatif, dan (.) menotasikan $\hat{\rho}_{i j}(k)$ berada diantara \pm 2 kali standard errors dan menunjukkan tidak adanya korelasi.

\subsubsection{Partial Matrix Autocorrelation Function (MACF)}

Tiao dan Box (1981) dalam Wei (2006) yang mendefinisikan matriks autokorelasi parsial pada lag $\mathrm{k}$ dengan notasi $\mathcal{P}(k)$. Persamaan untuk matriks autokorelasi parsial adalah sebagai berikut:

$$
\boldsymbol{P}(k)=\left\{\begin{array}{lr}
\boldsymbol{\Gamma}^{\prime}(1)[\boldsymbol{\Gamma}(0)]^{-1} & , k=1 \\
\left(\boldsymbol{\Gamma}^{\prime}(k)-\boldsymbol{c}^{\prime}(k)[\boldsymbol{A}(k)]^{-1} \boldsymbol{b}(k)\right)\left(\boldsymbol{\Gamma}(0)-\boldsymbol{b}^{\prime}(k)[\boldsymbol{A}(k)]^{-1} \boldsymbol{b}(k)\right)^{-1}, k>1
\end{array}\right.
$$

dengan nilai $\mathbf{A}(\mathrm{k}), \mathbf{b}(\mathrm{k})$, dan $\mathbf{c}(\mathrm{k})$ adalah sebagai berikut:

$$
\boldsymbol{A}(k)=\left[\begin{array}{cccc}
\boldsymbol{\Gamma}(0) & \boldsymbol{\Gamma}^{\prime}(1) & \cdots & \boldsymbol{\Gamma}^{\prime}(k-2) \\
\boldsymbol{\Gamma}(1) & \boldsymbol{\Gamma}(0) & \cdots & \boldsymbol{\Gamma}^{\prime}(k-3) \\
\vdots & \vdots & \ddots & \vdots \\
\boldsymbol{\Gamma}(k-2) & \boldsymbol{\Gamma}(k-3) & \cdots & \boldsymbol{\Gamma}(0)
\end{array}\right], \boldsymbol{b}(k)=\left[\begin{array}{c}
\boldsymbol{\Gamma}^{\prime}(k-1) \\
\boldsymbol{\Gamma}^{\prime}(k-2) \\
\vdots \\
\boldsymbol{\Gamma}^{\prime}(1)
\end{array}\right], \boldsymbol{c}(k)=\left[\begin{array}{c}
\boldsymbol{\Gamma}(1) \\
\boldsymbol{\Gamma}(2) \\
\vdots \\
\boldsymbol{\Gamma}(k-1)
\end{array}\right]
$$

Stasioneritas dari multivariate time series selain dapat dilihat dari plot MACF dan MPACF, juga dapat dilihat dari eigen value parameter model VAR (Wei, 2006). Misalkan model VAR (1) sebagai berikut:

$$
\left(1-\boldsymbol{\Phi}_{1} B\right) \boldsymbol{Z}_{t}=\boldsymbol{a}_{t}, \text { dimana } \boldsymbol{\Phi}_{1}=\left[\begin{array}{ll}
\phi_{11} & \phi_{12} \\
\phi_{21} & \phi_{22}
\end{array}\right]
$$

Menurut Wei (2006) jika eigen value dari $\boldsymbol{\Phi}_{1}<1$, yang berarti berada di dalam lingkaran satuan maka dapat dikatakan bahwa proses stasioner.

\subsubsection{Akaike's Information Criterion (AIC)}

Kriteria dalam pemilihan model terbaik yang diperkenalkan oleh Akaike (1973), suatu model dikatakan baik apabila nilai AIC-nya paling kecil. 


$$
\operatorname{AIC}(p)=\log \left|\widehat{\boldsymbol{\Sigma}}_{p}\right|+\frac{2}{T} p K^{2}
$$

dimana $\widehat{\boldsymbol{\Sigma}}_{p}=T^{-1} \sum_{i=1}^{T} \hat{\boldsymbol{e}}_{t} \hat{\boldsymbol{e}}_{t}^{\prime}$ adalah matriks penduga kovarian residual untuk model $\operatorname{VAR}($ p). T merupakan ukuran sampel dan $\mathrm{K}$ merupakan banyak variabel.

\subsection{Model Generalized Space Time Autoregressive (GSTAR)}

Model Generalized Space Time Autoregressive (GSTAR) merupakan generalisasi dari model Space Time Autoregressive (STAR). Model GSTAR mengasumsikan parameter autoregresif berbeda untuk setiap lokasi (heterogen) artinya parameter autoregresif pada model bukan merupakan konstanta melainkan dalam bentuk matriks.

Jika diketahui data time series $\{Z(t): t=0,1,2, .$.$\} merupakan sebuah multivariate$ time series dari $\mathrm{N}$ pengamatan, maka model GSTAR dengan orde autoregresif (waktu) $\operatorname{AR}(p)$ dan orde spasial $\left(\lambda_{1}, \lambda_{2}, \ldots, \lambda_{p}\right)$ (Borovkova et al., 2002):

$$
\boldsymbol{Z}(t)=\sum_{k=1}^{p}\left[\boldsymbol{\Phi}_{k 0}+\sum_{l=1}^{\lambda_{p}} \boldsymbol{\Phi}_{k l} \boldsymbol{W}^{(l)}\right] \boldsymbol{Z}(t-k)+\boldsymbol{\varepsilon}(t)
$$

dengan

$\boldsymbol{\Phi}_{k 0}: \operatorname{diag}\left(\emptyset_{k 0}^{(1)}, \ldots, \emptyset_{k 0}^{(N)}\right)$ merupakan parameter autoregresif, $\mathrm{k}=1,2, \ldots, \mathrm{p}$

$\boldsymbol{\Phi}_{k l}: \operatorname{diag}\left(\emptyset_{k l}^{(1)}, \ldots, \emptyset_{k l}^{(N)}\right)$ merupakan parameter spasial regresi, $\mathrm{l}=1,2, \ldots, \lambda_{p}$

$\boldsymbol{W}^{(l)}$ : matriks bobot $(N \times N)$ dengan nilai pembobot yang dipilih agar memenuhi syarat $w_{i i}^{(l)}=0 \quad$ dan $\quad \sum_{i \neq j} w_{i j}^{(l)}=1, i=1,2, \ldots, N$

$\boldsymbol{\varepsilon}(t)$ : vektor residual $(N \times 1)$ yang independen, identik, berdistribusi normal multivariat dengan mean nol dan matriks varian-kovarian $\sigma^{2} \boldsymbol{I}_{N}$

$\boldsymbol{Z}(t)$ : vektor acak berukuran $(N \times 1)$ pada waktu $\mathrm{t}$

\subsubsection{Identifikasi Model GSTAR}

\section{a. Orde Spasial}

Karakter model spasial ditandai oleh adanya ketergantungan linier pada lokasi. Tingkat perubahan ketergantungan lokasi dinamakan orde spasial dilambangkan dengan $l$, dengan $l=1,2, \ldots, \lambda_{p}$. Orde spasial merupakan urutan berdasarkan jarak dari suatu lokasi tertentu ke semua lokasi yang ada disekitarnya (Prasetya, 2017).

\section{b. Orde Waktu}

Identifikasi orde waktu dapat dilakukan dengan menggunakan nilai AIC yang minimum (Wei, 2006), akan tetapi penentuan orde model berdasarkan nilai AIC tidak dapat menangkap pola seasonal. Oleh karena itu penentuan orde waktu dapat dilakukan berdasarkan plot MACF dan MPACF yang terbentuk (Wutsqa dan Suhartono, 2010).

\subsubsection{Pemilihan Bobot Lokasi pada Model GSTAR}

a. Bobot Seragam

Bobot lokasi seragam memberikan nilai bobot yang sama untuk setiap lokasi.

$$
w_{i j}^{(k)}=\left\{\begin{array}{c}
\frac{1}{n_{i}}, i \neq j \\
0, \text { lainnya }
\end{array}\right.
$$

dengan $n_{i}$ adalah jumlah lokasi yang berdekatan dengan lokasi i 


\section{b. Bobot Biner}

Pembobotan dengan metode biner memiliki pembobot dengan $w_{i j}=0$ atau 1. Jarak lokasi terdekat akan bernilai 1, sedangkan jarak lokasi yang lebih jauh bernilai 0 .

\section{c. Bobot Invers Jarak}

Bobot invers jarak didapatkan dari perhitungan berdasarkan jarak sebenarnya antar lokasi. Perhitungan bobot invers jarak adalah sebagai berikut:

1. Bobot bernilai 0 jika $\mathrm{i}=\mathrm{j}$.

2. Beri kode urutan jarak dari dekat ke jauh dan sebaliknya dari paling jauh ke paling dekat.

3. Hitung $\sum_{i \neq j} w_{i j}$.

4. Lokasi dengan jarak terjauh medapat bobot $w_{i j}=\frac{(\text { jarak terdekat })_{i}}{\sum_{i \neq j} w_{i j}}$

\section{d. Bobot Normalis asi Korelasi Silang}

Penentuan nilai bobot normalisasi korelasi silang menggunakan hasil normalisasi korelasi silang antar lokasi pada lag yang bersesuaian (Suhartono dan Atok, 2006), Taksiran dari korelasi silang pada sampel dapat dinyatakan dalam bentuk

$$
r_{i j}(k)=\frac{\sum_{t=k+1}^{n}\left[Z_{i}(t)-\bar{Z}_{i}\right]\left[Z_{j}(t-k)-\bar{Z}_{j}\right]}{\sqrt{\left(\sum_{t=1}^{n}\left[Z_{i}(t)-\bar{Z}_{i}\right]^{2}\right)\left(\sum_{t=1}^{n}\left[Z_{j}(t)-\bar{Z}_{j}\right]^{2}\right)}}
$$

bobot berdasarkan pada normalisasi korelasi silang dirumuskan sebagai berikut:

$$
w_{i j}=\frac{r_{i j}(k)}{\sum_{j \neq i}\left|r_{i j}(k)\right|}
$$

dengan $\mathrm{i} \neq \mathrm{j}$, dan bobot ini memenuhi $\sum_{i \neq j}\left|w_{i j}\right|=1$

\subsubsection{Es timasi Parame ter dengan Metode Ordinary Least Square (OLS)}

Model GSTAR dapat diestimasi menggunakan metode kuadrat terkecil atau least square dengan meminimumkan jumlah kuadrat residualnya (Borovkova et al., 2008). Model GSTAR $\left(\mathrm{I}_{1}\right)$ dapat ditulis dalam bentuk linier sebagai berikut:

$$
\boldsymbol{Y}=\boldsymbol{X} \boldsymbol{\beta}+\boldsymbol{\varepsilon}
$$

Penjabaran matriksnya sebagai berikut ini:

$$
\boldsymbol{Y}=\left[\begin{array}{c}
\boldsymbol{Y}_{1} \\
\boldsymbol{Y}_{2} \\
\vdots \\
\boldsymbol{Y}_{N}
\end{array}\right], \boldsymbol{X}=\left[\begin{array}{cccc}
\boldsymbol{X}_{1} & 0 & \cdots & 0 \\
0 & \boldsymbol{X}_{2} & \cdots & 0 \\
\vdots & \vdots & \ddots & \vdots \\
0 & 0 & \cdots & \boldsymbol{X}_{N}
\end{array}\right], \boldsymbol{\beta}=\left[\begin{array}{c}
\boldsymbol{\beta}_{1} \\
\boldsymbol{\beta}_{2} \\
\vdots \\
\boldsymbol{\beta}_{N}
\end{array}\right], \varepsilon=\left[\begin{array}{c}
\boldsymbol{e}_{1} \\
\boldsymbol{e}_{2} \\
\vdots \\
\boldsymbol{e}_{N}
\end{array}\right]
$$

Model persamaan untuk lokasi ke-i dapat ditulis sebagai $\boldsymbol{Y}_{i}=\boldsymbol{X}_{i} \boldsymbol{\beta}_{i}+\boldsymbol{e}_{i}$ dengan $\boldsymbol{\beta}_{i}=\left(\varnothing_{i 0}^{1}, \emptyset_{i 1}^{1}\right)^{\prime}$. Penjabaran matriksnya untuk setiap $\mathrm{i}=1,2, \ldots, \mathrm{N}$ sebagai berikut:

$\boldsymbol{Y}_{i}=\left[\begin{array}{c}Z_{i}(2) \\ Z_{i}(3) \\ \vdots \\ Z_{i}(T)\end{array}\right], \quad \boldsymbol{X}_{i}=\left[\begin{array}{cc}Z_{i}(1) & V_{i}(1) \\ Z_{i}(2) & V_{i}(2) \\ \vdots & \vdots \\ Z_{i}(T-1) & V_{i}(T-1)\end{array}\right], \quad \boldsymbol{\beta}_{i}=\left[\begin{array}{c}\emptyset_{i 0}^{1} \\ \emptyset_{i 1}^{1}\end{array}\right], \quad \boldsymbol{e}_{i}=\left[\begin{array}{c}e_{i}(2) \\ e_{i}(3) \\ \vdots \\ e_{i}(T)\end{array}\right]$

dengan $Z_{i}(t)$ merupakan banyaknya pengamatan dengan $\mathrm{t}=1,2, \ldots, \mathrm{T}$ untuk lokasi $\mathrm{i}=1,2, \ldots, \mathrm{N}$ dan $V_{i}(T)=\sum_{j=1}^{N} w_{i j} Z_{j}(t)$ untuk $\mathrm{i} \neq \mathrm{j}$.

Nilai taksiran untuk parameter model adalah sebagai berikut:

$$
\widehat{\boldsymbol{\beta}}=\left[\boldsymbol{X}^{\prime} \boldsymbol{X}\right]^{-1} \boldsymbol{X}^{\prime} \boldsymbol{Y}
$$




\subsubsection{Estimasi Parameter Model Seemingly Unrelated Regression (SUR) dengan Metode Generalisasi Least Square (GLS)}

Model Seemingly Unrelated Regression (SUR) adalah model regresi linear multivariat yang diperkenalkan oleh Zellner (1962). Model SUR dapat diestimasi menggunakan metode Generalized Least Square (GLS), residual pada model GSTAR berkorelasi antar persamaan, sehingga dapat diatasi dengan menggunakan pendekatan SUR (Seemingly Unrelated Regression).

Estimasi parameter pada model SUR dengan metode GLS memerlukan invers dari matriks varian kovarian residual $\boldsymbol{\Omega}^{-1}=\boldsymbol{\Sigma}^{-1} \otimes \boldsymbol{I}$. Sehingga diperoleh penaksir tak bias $\boldsymbol{\beta}$ dengan metode GLS, yaitu:

$$
\widehat{\boldsymbol{\beta}}=\left(\boldsymbol{X}^{\prime} \boldsymbol{\Omega}^{-1} \boldsymbol{X}\right)^{-1} \boldsymbol{X}^{\prime} \boldsymbol{\Omega}^{-1} \boldsymbol{Y}
$$

\subsection{Pengujian Asumsi Residual}

\subsubsection{Asumsi White Noise Residual}

Residual bersifat white noise berarti residual dari masing-masing data saling independen. Pengecekan asumsi white noise residual dapat dilihat menggunakan ACF atau PACF dari residual. Jika setiap plot ACF tidak signifikan secara statistik terhadap 2 kali standard error dari ACF residual, maka residual bersifat white noise (Wei, 1994). Cara lain yang dapat digunakan adalah dengan kriteria minimum AIC dari residual. Jika nilai AIC residual terkecil berada pada lag ke-0 maka dapat dikatakan bahwa tidak ada korelasi antar masing-masing residual, yang berarti residual bersifat white noise.

\subsubsection{Asumsi Distribusi Normal Multivariat Residual}

Hipotesis:

$H_{0}: F(x)=F_{0}(x)$ (Residual berdistribusi normal multivariat)

$H_{1}: F(x) \neq F_{0}(x)$ (Residual tidak berdistribusi normal multivariat)

Statistik Uji:

$D=\sup _{\mathrm{x}}\left|F(x)-F_{0}(x)\right|$

dengan $\mathrm{x}$ merupakan jarak kuadrat mahalanobis $\left(d_{i}^{2}\right) . \mathrm{F}(\mathrm{x})$ adalah fungsi peluang kumulatif yang dihitung dari data sampel, dan $\mathrm{F}_{0}(\mathrm{x})$ adalah fungsi distribusi data yang dihipotesiskan. Kriteria Uji:

Tolak $\mathrm{H}_{0}$ jika $D \geq D_{(1-\alpha), r}$ atau p-value $<\alpha$ dengan $D_{(1-\alpha), r}$ adalah nilai dari tabel Kolmogorov Smirnov dengan kuantil 1- $\alpha$.

\subsubsection{Uji Kovarian}

Sebelum memodelkan GSTAR dengan Seemingly Unrelated Regression (SUR) perlu dilakukan uji kovarian untuk mengetahui residual antar persamaan berkorelasi atau tidak. Rasio statistik Likelihood dapat digunakan untuk menguji apakah kovarian tidak sama dengan nol antara persamaan-persamaan tersebut.

$\lambda_{L R}=T\left[\sum_{i}^{n} \ln S_{n}^{2}-\ln |\widehat{\mathbf{\Omega}}|\right]$

dengan $S_{n}^{2}$ adalah dugaan dari ragam residual pada tiap persamaan OLS dan $\boldsymbol{\Omega}$ adalah dugaan dari matriks residual varian-kovarian. Nilai uji statistik ini dibandingkan dengan nilai tabel $\chi^{2}$ dengan derajat bebas $n(n-1) / 2$. 


\subsection{Pemilihan Model Terbaik}

\subsubsection{Mean Absolute Percentage Error (MAPE)}

Mean Absolute Percentage Error (MAPE) merupakan salah satu ukuran yang dapat dijadikan acuan dalam mengevaluasi keakuratan suatu model.

$M A P E=\frac{\sum_{i=1}^{m}\left|\left(\frac{z_{t}-z_{t}}{z_{t}}\right) \times 100 \%\right|}{m}$

\subsubsection{Root Mean Square Error (RMSE)}

Salah satu alternatif untuk pemilihan model berdasarkan nilai error adalah RMSE.

$$
R M S E=\sqrt{M S E}=\sqrt{\frac{1}{m} \sum_{i=1}^{m}\left(Z_{t}-\hat{Z}_{t}\right)^{2}}
$$

\section{METODE PENELITIAN}

\subsection{Sumber Data dan Variabel Penelitian}

Data yang digunakan dalam penelitian ini merupakan data sekunder, yaitu data Indeks Harga Konsumen (IHK) umum di Purwokerto, Surakarta, Semarang, dan Tegal tahun dasar 2007 yaitu dari bulan Juni 2008 hingga Desember 2013 yang diperoleh dari website resmi Badan Pusat Statistik Jawa Tengah yaitu jateng.bps.go.id. Terdapat empat variabel yang digunakan dalam penelitian ini, yaitu

$$
\begin{aligned}
& Z_{1}(t)=\text { IHK di Purwokerto } \\
& Z_{2}(t)=\text { IHK di Surakarta } \\
& Z_{3}(t)=\text { IHK di Semarang } \\
& Z_{4}(t)=\text { IHK di Tegal }
\end{aligned}
$$

\subsection{Langkah-langkah Analisis Data}

Tahapan analisis yang dilakukan dalam penelitian ini sebagai berikut:

1. Menentukan data deret waktu dan lokasi yang akan digunakan dalam penelitian.

2. Menentukan orde waktu dari model GSTAR yang sesuai berdasarkan hasil identifikasi pada model VAR dengan menggunakan MACF, MPACF, dan AIC minimum.

3. Membentuk model GSTAR-OLS dengan langkah-langkah sebagai berikut ini:

a. Menetapkan nilai bobot lokasi dengan empat jenis bobot lokasi

b. Melakukan penaksiran parameter dari model GSTAR-OLS untuk masing-masing bobot lokasi.

c. Menguji signifikansi parameter model GSTAR-OLS untuk masing-masing bobot lokasi.

4. Menguji apakah terdapat korelasi residual antar lokasi dengan uji kovarian, apabila terdapat korelasi residual antar lokasi maka dibentuk model GSTAR-SUR

5. Membentuk model GSTAR-SUR dengan langkah-langkah sebagai berikut ini:

a. Melakukan penaksiran parameter dari model GSTAR dengan model Seemingly Unrelated Regression (SUR) dengan metode Generalized Least Square (GLS) untuk masing- masing bobot lokasi.

b. Menguji signifikansi parameter model GSTAR-SUR untuk masing-masing bobot lokasi.

c. Menguji residual model GSTAR-OLS untuk masing-masing bobot lokasi dengan uji asumsi residual yaitu uji white noise dan normal multivariat

6. Menentukan model GSTAR-SUR dengan jenis bobot lokasi terbaik berdasarkan nilai MAPE dan RMSE. 


\section{HASIL DAN PEMBAHASAN}

\subsection{Analis is Deskriptif}

Pola pergerakan data IHK empat kota cenderung sama setiap bulannya yang memungkinkan adanya efek saling berkaitan antar keempat kota tersebut.

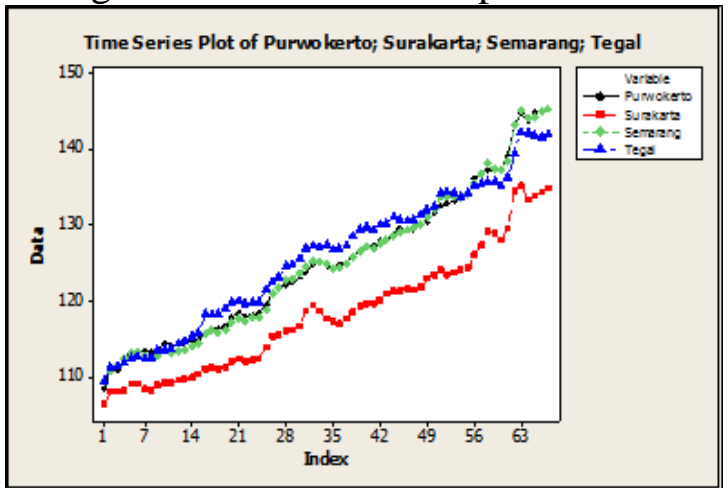

Gambar 1. Plot Time Series Data IHK di Empat Kota

Kecenderungan IHK yang saling berkaitan antarkota dapat dilihat dari nilai korelasi antarkota yang sangat tinggi seperti pada Tabel 1 berikut ini:

Tabel 1. Nilai Korelasi Data IHK Empat Kota di Jawa Tengah

\begin{tabular}{ccccc}
\hline Lokasi & Purwokerto & Surakarta & Semarang & Tegal \\
\hline Purwokerto & 1 & & & \\
$P$-Value & $0,000^{*}$ & & & \\
Surakarta & 0,997 & & & \\
$P$-Value & $0,000^{*}$ & 1 & & \\
Semarang & 0,999 & 0,997 & 1 & \\
$P$-Value & $0,000^{*}$ & $0,000^{*}$ & $0,000^{*}$ & \\
Tegal & 0,985 & 0,979 & 0,987 & 1 \\
$P$-Value & $0,000^{*}$ & $0,000^{*}$ & $0,000^{*}$ & $0,000^{*}$ \\
\hline * Signifikan pada $\alpha=5 \%$ & & &
\end{tabular}

\subsection{Pemodelan Generalized Space Time Autoregressive (GSTAR)}

\subsubsection{Identifikasi Model GSTAR} berikut:

Tahapan identifikasi pada pemodelan GSTAR yang perlu dilakukan sebagai

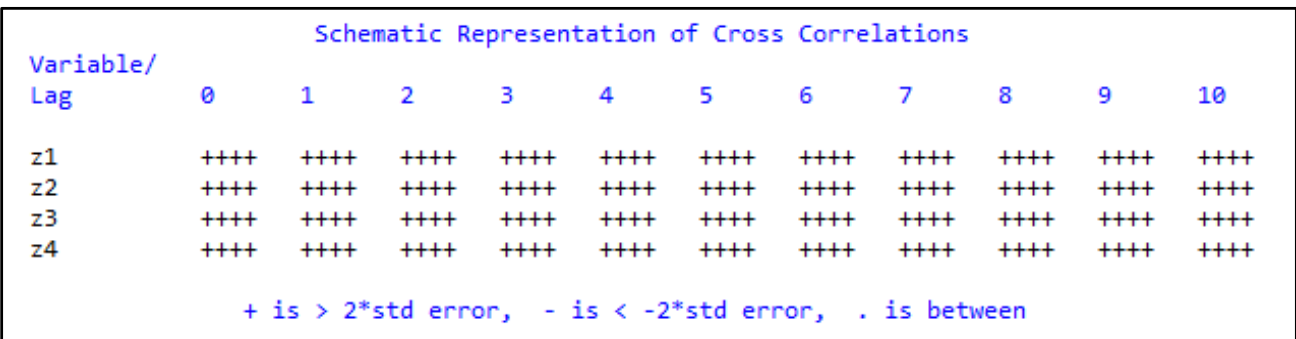

Gambar 2. Plot MACF Data IHK di Empat Lokasi

Terlihat pada Gambar 2 semua lag terdapat nilai korelasi yang melebihi 2 kali standard errors. Hal ini ditunjukkan oleh banyaknya simbol (+) pada MACF sehingga data $\mathrm{Z}_{1}(\mathrm{t}), \mathrm{Z}_{2}(\mathrm{t}), \mathrm{Z}_{3}(\mathrm{t})$ dan $\mathrm{Z}_{4}(\mathrm{t})$ tidak stasioner dalam mean dan perlu dilakukan differencing. 


\begin{tabular}{|c|c|c|c|c|c|c|c|c|c|c|c|}
\hline \multirow{2}{*}{$\begin{array}{l}\text { Variable/ } \\
\text { Lag }\end{array}$} & \multicolumn{3}{|c|}{ Schematic } & presen & ation & f Cros & \multicolumn{2}{|c|}{ Correlations } & \multirow[b]{2}{*}{8} & \multirow[b]{2}{*}{9} & \multirow[b]{2}{*}{10} \\
\hline & 0 & 1 & 2 & 3 & 4 & 5 & 6 & 7 & & & \\
\hline$z 1$ & ++++ & $\ldots++$ &.. &.-- & $\ldots$ & $\ldots$ & $\ldots+$ & $\ldots$ & $\ldots$ & $\ldots$ & $\ldots$ \\
\hline$z 2$ & ++++ & $\ldots++$ & $\cdot-\ldots$ & $\ldots$ & $\ldots$ & $\ldots$ & $\ldots$ & $\ldots$ & $\ldots$ & $\ldots$ & $\ldots$ \\
\hline$z 3$ & ++++ & $\ldots++$ & $\cdots$ & $\ldots$ & $\ldots$ & $\ldots$ & $\ldots$ & $\ldots$ & $\ldots$ & $\ldots$ & $\cdots$ \\
\hline$z 4$ & ++++ & $\ldots$ & $\cdot-\ldots$ & $\ldots-$ & $\cdots$ & $\ldots$ & $\cdots$ & $\cdots$ & $\cdot-\ldots$ & $\ldots$ & $\cdots$ \\
\hline
\end{tabular}

Gambar 3. Plot MACF Data IHK di Empat Lokasi Setelah Differencing 1

Stasioneritas dari data multivariate time series selain dilihat dari plot MACF dan MPACF, juga dapat dilihat dari eigen value parameter model VAR (Wei, 2006).

$\boldsymbol{\Phi}=\left[\begin{array}{cccc}0,200153 & -0,07316 & 0,617753 & 0,185731 \\ -0,06431 & 0,613236 & 0,200918 & 0,137049 \\ -0,27807 & 0,011387 & 0,980275 & 0,254693 \\ -0,43794 & 0,111260 & 0,149815 & 1,154836\end{array}\right]$

Nilai eigen dari matriks $\boldsymbol{\Phi}$ adalah sebagai berikut:

$\lambda_{1}=0,541306, \lambda_{2}=0,541306, \lambda_{3}=0,93367$, dan $\lambda_{4}=0,93367$

Karena semua nilai eigen (eigen value) yang diperoleh kurang dari 1 yang berarti berada di dalam lingkaran satuan, maka dapat dikatakan bahwa data sudah stasioner

Setelah data stasioner, maka langkah selanjutnya adalah mencari orde waktu model GSTAR melalui identifikasi model Vector Autoregressive (VAR). Melalui MPACF terlihat bahwa lag yang keluar melebihi \pm 2 kali standard errors terdapat pada lag 1, 2, 3, 5, dan 7 .

\begin{tabular}{|c|c|c|c|c|c|c|c|c|c|c|}
\hline \multirow{2}{*}{$\begin{array}{l}\text { Variable/ } \\
\text { Lag }\end{array}$} & \multicolumn{9}{|c|}{ Schematic Representation of Partial Cross Correlations } & \multirow[b]{2}{*}{10} \\
\hline & 1 & 2 & 3 & 4 & 5 & 6 & 7 & 8 & 9 & \\
\hline$z 1$ & $\ldots+$ & $\ldots$ & $\ldots-$ & $\ldots$ & $\ldots-$ & $\ldots$ & $\ldots+$ & $\ldots$ & $\ldots$ & $\ldots$ \\
\hline$z 2$ & $\ldots+$ & $-\ldots$ & $\ldots$ & $\ldots$ & $\ldots$ & $\cdots$ & $\ldots+$ & $\ldots$ & $\ldots$ & $\ldots$ \\
\hline z3 & $\ldots$ & $\ldots$ & $\ldots$ & $\ldots$ & $+\ldots$ & $\ldots$ & $\ldots$ & $\ldots$ & $\ldots$ & $\ldots$ \\
\hline$z 4$ & $\ldots$ & $\ldots$ & $\ldots$ & $\ldots$ & $\ldots$ & $\ldots$ & $\ldots$ & $\ldots$ & $\ldots$ & $\ldots$ \\
\hline
\end{tabular}

Gambar 4. Plot MPACF Data IHK di Empat Lokasi Setelah Differencing 1

Model VAR yang terbentuk dari identifikasi pada tahap ini adalah model VAR dengan orde $\mathrm{p}=1$ karena memiliki nilai AIC terkecil yaitu $-137,105$ yang terdapat pada $A R=1$ seperti terlihat pada Gambar 5 dan AIC minimum yaitu $-6,151384$ terletak pada $A R=1$ dan $\mathrm{MA}=0$ seperti terlihat pada Gambar 6. Sehingga model GSTAR yang digunakan dalam data IHK di Purwokerto, Surakarta, Semarang, dan Tegal adalah GSTAR (1 1$) 1(1)$.

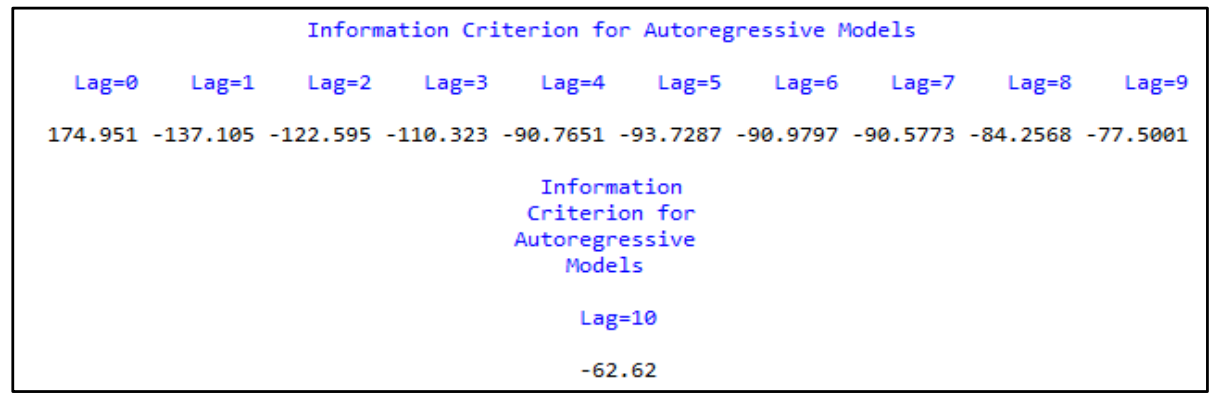

Gambar 5. AIC Autoregressive Data IHK Empat Lokasi Setelah dilakukan Differencing 1 


\begin{tabular}{|c|c|c|c|c|c|c|}
\hline \multicolumn{7}{|c|}{ Minimum Information Criterion } \\
\hline Lag & MA 0 & MA 1 & MA 2 & MA 3 & MA 4 & MA 5 \\
\hline AR 0 & -5.952025 & -5.320338 & -4.982858 & -4.7395 & -4.291605 & -4.05522 \\
\hline AR 1 & -6.151384 & -5.397504 & -5.190239 & -5.124566 & -4.333268 & -3.797123 \\
\hline AR 2 & -5.982288 & -5.351376 & -4.839397 & -4.698586 & -3.952723 & -3.275088 \\
\hline AR 3 & -5.71739 & -5.305937 & -4.620581 & -3.780177 & -2.88278 & -1.695867 \\
\hline AR 4 & -5.249739 & -4.792639 & -4.215846 & -3.178912 & -1.702787 & 0.586625 \\
\hline AR 5 & -5.20068 & -4.429345 & -3.657692 & -1.924947 & 0.1110091 & 3.5176325 \\
\hline
\end{tabular}

Gambar 6. Nilai AIC Proses AR dan MA Data IHK Empat Lokasi Setelah Differencing 1

\subsubsection{Penentuan Bobot Lokasi pada GSTAR}

a. Bobot Seragam

Hasil perhitungan matriks bobot seragam sebagai berikut:

$$
\boldsymbol{W}=\left[\begin{array}{cccc}
0 & 0,333 & 0,333 & 0,333 \\
0,333 & 0 & 0,333 & 0,333 \\
0,333 & 0,333 & 0 & 0,333 \\
0,333 & 0,333 & 0,333 & 0
\end{array}\right]
$$

b. Bobot Biner

Hasil perhitungan matriks bobot biner sebagai berikut:

$$
\boldsymbol{W}=\left[\begin{array}{llll}
0 & 1 & 1 & 1 \\
1 & 0 & 1 & 1 \\
1 & 1 & 0 & 1 \\
1 & 1 & 1 & 0
\end{array}\right]
$$

c. Bobot Invers Jarak

Hasil perhitungan matriks bobot invers jarak sebagai berikut:

$$
\boldsymbol{W}=\left[\begin{array}{cccc}
0 & 0,204 & 0,395 & 0,401 \\
0,378 & 0 & 0,450 & 0,172 \\
0,209 & 0,453 & 0 & 0,338 \\
0,489 & 0,209 & 0,302 & 0
\end{array}\right]
$$

\section{d. Bobot Normalis asi Kore lasi Silang}

Hasil perhitungan matriks bobot normalisasi korelasi silang sebagai berikut:

$$
\boldsymbol{W}(1)=\left[\begin{array}{cccc}
0 & 0,438 & 0,309 & 0,253 \\
0,611 & 0 & 0,259 & 0,129 \\
0,411 & 0,374 & 0 & 0,215 \\
0,344 & 0,356 & 0,300 & 0
\end{array}\right]
$$

\subsection{Pemilihan Model Terbaik}

Setelah dilakukan estimasi paramater model GSTAR-SUR $\left(1_{1}\right) \mathrm{I}(1)$ dengan empat bobot lokasi yaitu bobot seragam, bobot biner, bobot invers jarak, dan bobot normalisasi korelasi silang. Kemudian uji asumsi white noise dan normal multivariat. Diperoleh model terbaik berdasarkan indikator-indikator pada Tabel 2 yaitu model GSTAR-SUR $\left(1_{1}\right) \mathrm{I}(1)$ dengan bobot normalisasi korelasi silang karena residual bersifat white noise dengan ratarata nilai MAPE sebesar 0,4455\% dan rata-rata nilai RMSE sebesar 0,80582. 
Tabel 2. Ringkasan Uji Asumsi Residual, MAPE, dan RMSE

\begin{tabular}{|c|c|c|c|c|c|}
\hline Model & Indikator & Seragam & Biner & Invers Jarak & $\begin{array}{l}\text { Normalisasi } \\
\text { Korelasi Silang }\end{array}$ \\
\hline \multirow{14}{*}{$\begin{array}{c}\text { GSTAR } \\
\text {-SUR } \\
\left(\mathbf{1}_{1}\right) \mathbf{I}(\mathbf{1})\end{array}$} & White Noise & $\begin{array}{c}\text { Tidak white } \\
\text { noise }\end{array}$ & $\begin{array}{c}\text { Tidak white } \\
\text { noise }\end{array}$ & white noise & white noise \\
\hline & $\begin{array}{c}\text { Normal } \\
\text { Multivariat }\end{array}$ & $\begin{array}{c}\text { Tidak normal } \\
\text { multivariat }\end{array}$ & $\begin{array}{c}\text { Tidak normal } \\
\text { multivariat }\end{array}$ & $\begin{array}{c}\text { Tidak normal } \\
\text { multivariat }\end{array}$ & $\begin{array}{c}\text { Tidak normal } \\
\text { multivariat }\end{array}$ \\
\hline & \multicolumn{5}{|c|}{ MAPE } \\
\hline & Purwokerto & $0,422 \%$ & $0,422 \%$ & $0,423 \%$ & $0,418 \%$ \\
\hline & Surakarta & $0,492 \%$ & $0,492 \%$ & $0,489 \%$ & $0,490 \%$ \\
\hline & Semarang & $0,432 \%$ & $0,432 \%$ & $0,434 \%$ & $0,434 \%$ \\
\hline & Tegal & $0,435 \%$ & $0,435 \%$ & $0,433 \%$ & $0,439 \%$ \\
\hline & Rata-rata MAPE & $0,4450 \%$ & $0,4348 \%$ & $0,4449 \%$ & $0,4455 \%$ \\
\hline & \multicolumn{5}{|c|}{ RMSE } \\
\hline & Purwokerto & 0,801425 & 0,801425 & 0,802291 & 0,798802 \\
\hline & Surakarta & 0,916207 & 0,916207 & 0,910582 & 0,912068 \\
\hline & Semarang & 0,788542 & 0,788542 & 0,792726 & 0,787589 \\
\hline & Tegal & 0,729415 & 0,729415 & 0,734349 & 0,72482 \\
\hline & Rata-rata RMSE & 0,808897 & 0,808897 & 0,809987 & 0,80582 \\
\hline
\end{tabular}

Persamaan model terbaik untuk data IHK empat kota di Jawa Tengah adalah model GSTAR-SUR $\left(1_{1}\right) \mathrm{I}(1)$ dengan bobot normalisasi korelasi silang sebagai berikut :

i. Persamaan model GSTAR-SUR untuk IHK di Purwokerto

$Z_{1}(t)=Z_{1}(t-1)+0,205 Z_{2}(t-1)-0,205 Z_{2}(t-2)+0,145 Z_{3}(t-1)$ $-0,145 Z_{3}(t-2)+0,118 Z_{4}(t-1)-0,118 Z_{4}(t-2)+e_{1}(t)$

ii. Persamaan model GSTAR-SUR untuk IHK di Surakarta $Z_{2}(t)=Z_{2}(t-1)+0,2777 Z_{2}(t-1)-0,2777 Z_{2}(t-2)+e_{2}(t)$

iii. Persamaan model GSTAR-SUR untuk IHK di Semarang $Z_{3}(t)=Z_{3}(t-1)+0,310 Z_{1}(t-1)-0,310 Z_{1}(t-2)+0,282 Z_{2}(t-1)$ $-0,282 Z_{2}(t-2)+0,162 Z_{4}(t-1)-0,162 Z_{4}(t-2)+e_{3}(t)$

iv. Persamaan model GSTAR-SUR untuk IHK di Tegal $Z_{4}(t)=Z_{4}(t-1)+0,172 Z_{1}(t-1)-0,172 Z_{1}(t-2)+0,178 Z_{2}(t-1)$ $-0,178 Z_{2}(t-2)+0,150 Z_{3}(t-1)-0,150 Z_{3}(t-2)+e_{4}(t)$

Berdasarkan model terbaik yaitu GSTAR-SUR $\left(1_{1}\right) \mathrm{I}(1)$ dengan bobot normalisasi korelasi silang dapat dianalisis bagaimana keterkaitan waktu dan lokasi pada data IHK empat kota di Jawa Tengah. Model GSTAR-SUR terbaik menjelaskan bahwa data IHK di Surakarta hanya dipengaruhi oleh waktu sebelumnya, tidak dipengaruhi oleh lokasi lainnya. Sedangkan data IHK di Purwokerto, Semarang, dan Tegal selain dipengaruhi oleh waktu sebelumnya juga dipengaruhi antar lokasi.

\section{KESIMPULAN}

Berdasarkan hasil analisis dan pembahasan mengenai data IHK di Purwokerto, Surakarta, Semarang, dan Tegal dapat disimpulkan bahwa Model GSTAR yang terbaik adalah model GSTAR-SUR $\left(1_{1}\right) \mathrm{I}(1)$ dengan bobot normalisasi korelasi silang karena memenuhi asumsi white noise dan menghasilkan nilai RMSE terkecil yaitu 0,80582 dan nilai MAPE yaitu $0,4455 \%$ yang berarti data IHK di Surakarta hanya dipengaruhi oleh waktu sebelumnya, tidak dipengaruhi oleh lokasi lainnya. Sedangkan data IHK di Purwokerto, Semarang dan Tegal selain dipengaruhi oleh waktu sebelumnya juga dipengaruhi antarlokasi.

DAFTAR PUSTAKA

[BPS]. Badan Pusat Statistik. 2014. Indeks Harga Konsumen dan Inflasi Jawa Tengah 2013. Semarang : Badan Pusat Statistik. 
Borovkova, S.A., Lapuhaä, H.P., dan Ruchjana, B.N. 2002. Generalized STAR Model with Experimental Weight. Proceeding of the $17^{\text {th }}$ International Workshop on Statistical Modelling. Chania: pp. 143-152.

Borovkova, S.A., Lapuhaä, H.P., dan Ruchjana, B.N. 2008. Consistency and Asymptotic Normality of Least Square Estimators in Generalized STAR Models. Statistica Neerlandica Vol. 62, No. 4: Hal. 482-508.

Box, G.E.P., Jenkins, G.M., dan Reinsel G.C. 1994. Time Series Analysis: Forecasting and Control. Third Edition. Englewod Cliffs: Pretince Hall.

Prasetya, A.S. 2017. Model GSTAR dengan Variabel Eksogen Metrik dan Non Metrik untuk Peramalan Inflasi di Kalimantan. Tesis. Tidak Dipublikasikan. Surabaya : Institut Teknologi Sepuluh November.

Srivastava, V.K. dan T.D. Dwivedi. 1979. Estimation of Seemingly Unrelated Regression Equations Models: A Brief Survey. Journal Econometrics Vol. 10, Hal. 15-32.

Suhartono dan Atok, R.M. 2006. Pemilihan Bobot Lokasi yang Optimal pada Model GSTAR. Presented at National Mathematics Conference XIII. Semarang: Universitas Negeri Semarang.

Wei, W.W.S. 2006. Time Series Analysis Univariate and Multivariate Methods. Second Edition. USA: Pearson Education, Inc.

Wutsqa, D.U. dan Suhartono. 2010. Peramalan Deret Waktu Multivariate Seasonal pada Data Pariwisata dengan Model VAR-GSTAR. Jurnal Ilmu Dasar Vol. 11, No. 1: pp. 101:109.

Zellner, A. 1962. An Efficient Method of Estimating Seemingly Unrelated Regression Equations and Tests for Aggregation Bias. Journal of the American Statistical Association Vol. 57, No. 298: Hal. 348-368. 